\title{
Antipsychotic and behavior effect of the ethanolic extract from the bark of Maytenus macrocarpa (Ruiz \&Pav.) Briq.in mice
}

\author{
Claudia Zambrano Santoyo, ${ }^{1,2 a}$, Lucero Zúñiga Espinoza ${ }^{1,2, a}$, Rosario Zanabria Puente ${ }^{1,2 a}$, Joshi Zegarra Sánchez ${ }^{1,2 a}$, Nathaly Zaga \\ Quispe $^{1,2 a}$, Carlos Pante Medina ${ }^{1,2, b}$ and Alberto Salazar Granara ${ }^{1,2, c}$. \\ 'Universidad de San Martin de Porres, Facultad de Medicina Humana, Centro de Investigación de Medicina Tradicional y Farmacología. \\ ${ }^{2}$ Sociedad Científica de Estudiantes de Medicina de la Universidad de San Martin de Porres. \\ Junior researcher and medicine student:; ${ }^{b}$ Research technician in animal species ; ${ }^{\circ}$ Doctor in Medicine and Physician.
}

\begin{abstract}
Introduction: Different studies indicate that Maytenus has many effects and that $M$. obtusifolia species has a central nervous system depressant effect. Objective: To determine antipsychotic and behavior modifying effect of the Maytenus macrocarpa (Ruiz \& Pav.) Briq.ethanolic extract, using the forced swim test and Irwin test. Method: 77 albino mice were used, with an average weight of $25 \mathrm{~g}$. They were split into 7 groups and they were administered with Maytenus macrocarpa of $200 \mathrm{mg} / \mathrm{kg}, 400 \mathrm{mg} / \mathrm{kg}$, $600 \mathrm{mg} / \mathrm{kg}, 800 \mathrm{mg} / \mathrm{kg}, 1000 \mathrm{mg} / \mathrm{kg}$, caffeine $32 \mathrm{mg} / \mathrm{kg}$, diazepam $32 \mathrm{mg} /$ $\mathrm{kg}$, fluoxetine $30 \mathrm{mg} / \mathrm{kg}$, haloperidol $5 \mathrm{mg} / \mathrm{kg}$, distilled water (placebo) 0,1 $\mathrm{ml} / 10 \mathrm{~g}$, and a control group. The Irwin test was used to evaluate presence or absence of lethality, convulsions, Straub tail, sedation, excitement, abnormal gait, jumps, motor in coordination, abdominal writhes, piloerection, stereotypies, head twitches, scratching and breathing. The forced swim test was used to evaluate the antidepressant effects of each substance. Results: The highest immobility time was observed in Maytenus macrocarpa, compared with Haloperidol $(p>0.05)$ in the doses of $400 \mathrm{mg} / \mathrm{kg}$, both of the substances having a Gaussian distribution. Irwin test for Maytenus macrocarpa of $200 \mathrm{mg} / \mathrm{kg}$ had sedation effect at minute 30; doses of $400 \mathrm{mg} / \mathrm{kg}$ at minutes 15 and 45 , and doses of $600 \mathrm{mg} / \mathrm{kg}, 800 \mathrm{mg} / \mathrm{kg}$ and $1000 \mathrm{mg} / \mathrm{kg}$ at 15 minutes. Conclusion: Antipsychotic effects and behavior modifying effects were demonstrated in Maytenus macrocarpa (Ruiz and Pav.) Briq.ethanolic extract.
\end{abstract}

Key words: Antipsychotic, Antidepressive, Haloperidol, Maytenus, macrocarpa, Bark.

\section{SUMMARY}

- Maytenus macrocarpa demonstrated an antipsychotic effect and behavior modifying effect.

- Maytenus macrocarpa in doses of 200,600,800, and $1000 \mathrm{mg} / \mathrm{kg}$ showed a
non-Gaussian distribution

- The Irwin Test showed that sedation was the most important behavior after the use of Maytenus macrocarpa.

- The Forced Swim Test showed an inverse proportion correlation of dose-response compared with immobility time.

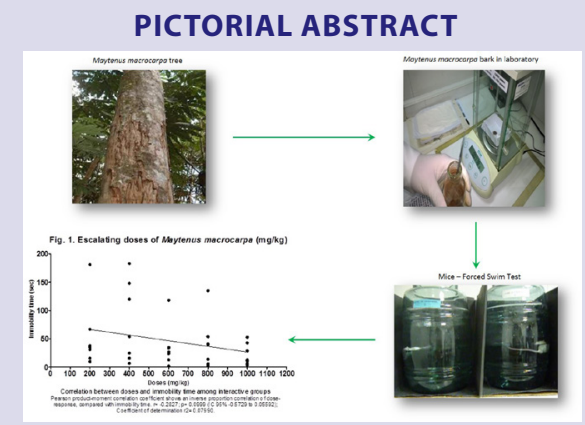

Abbreviations used: CNS: Central nervous system, ATP: Adenosine triphosphate, GABA: Gamma-aminobutyricacid.

Correspondence:

Dr. Alberto Salazar Granara, Avenida El Corregidor 1531, Urbanización Los Sirius, Las Viñas, La Molina, Lima, Perú. Extension 151.

Phone no: 5113652300

Email: asalazarg@usmp.pe

DOI : $10.5530 /$ pc.2015.4.5

\section{INTRODUCTION}

Peru has the fifth highest biodiversity of any country worldwide. It also has one of top number of species of plants with medicinal properties commonly used by the population. ${ }^{1}$ Maytenus macrocarpa (Ruiz \&Pav.) Briq, also known as "chuchuhuasi" is also called "master plant" because it is considered to have the ability to teach and show their own purposeto those who make use of it, like medicinal properties, or people's intentions, ${ }^{2}$ which is why "shamans" employ it.

Empirically, this plant is commonly used to relieve symptoms related to gastrointestinal system, colds and rheumatic complains. ${ }^{3}$ Researches have also demonstrated effects upon body temperature, heart and respiratory rate. ${ }^{4}$ It is also antinociceptive and potentially anti-inflammatory. ${ }^{5}$ Moreover, a negative effect upon mice spermatogenesis has been registered in which an abnormal morphology of spermatozoa was produced, probably due to chromosomalabnormalities. ${ }^{6}$ In addition, the Celastraceae family has demonstrated to have cytostatic, antitumoral, antileukemic, anorectic and abortive effects. ${ }^{7}$ Other species of genus Maytenus, for example M. aquifolium, $M$. robusta and M. obtusifolia MART have shown antiulcer activity. ${ }^{8-10}$ In Maytenus ilicifolia, acute diuretic activity and hipotensive activity were found, ${ }^{11}$ as well as antiprotozoal activity which was attributed to quinonemethide triterpenes. ${ }^{12}$

Furthermore, particular effects upon thecentral nervous system have been registered.M. obtusifolia'schloro form extracts have a central depressant effect,resulting in a significant decrease in spontaneous motor activity; also, it shows neuroleptic activity, shown as catalepsy, probably because of an interference with the central neurotransmission of dopamine. ${ }^{10}$

There are validated methods employed to evaluatethe effect of chemical substances upon CNS at a preclinical level.Theforced swim test, explores neuroleptic activity and/or antidepressant in mice, and the Irwin test, explores mice behavior. ${ }^{13-14}$ This study was focused in evaluating the possible antipsychotic and behavior effect of the ethanolic extract from the bark of Maytenus macrocarpa (Ruiz \& Pav.) Briq.in albino mice using forced swim test and Irwin test. 


\section{MATERIALS AND METHODS}

\section{Type of study, space and temporality}

It is an analytic, experimentaland triple-blind tudy, performed at Centro de Medicina Tradicional y Farmacología, Facultad de Medicina Humana, Universidad de San Martin de Porres (FMH-USMP); between February and November of 2014.

\section{Plant sample}

Bark from Maytenus macrocarpa was collected in the region of Madre de Dios (Sur-east, Peru). The plant was identified by Dr. Berta Loja Herrera (Centro de Investigación de Medicina Tradicional y Farmacología, FMH-USMP, Lima12, Peru). Voucher specimens are deposited at the Herbarium Vargas CUZ from the Universidad Nacional San Antonio Abad del Cuzco, numbers 3547 and 3653.

\section{Experimental animals}

77 male albino mice were used, with an average weight of $25 \mathrm{~g}$ from National Health Institute's vivarium (Lima-Peru). Ethical guidelines of the International Guiding Principles for Biomedical Research Involving Animal $^{21}$ were followed. Mice went through an acclimation process in the vivariumof the FMH-USMP, with a temperature of $22^{\circ} \mathrm{C}$ or $71.6^{\circ} \mathrm{F}$, humidity between $30-70 \%$, light/darkness cycles of 12 hours and noise levels less than $70 \mathrm{db}$. During this time the mice were maintained on a balanced diet and water ad libitum. Finally, 12 hours before the experiment food was taken away. For the cage's distribution and groups, we used the random assignment technique. ${ }^{22}$

\section{Chemistry sample}

We used Fluoxetin in tablets Sanitary Registry NG-2276., LabAC Farma S.A., EXP.: 06/2015; Haloperidol 5mg/5ml solution for injection ampoules SOL Sanitary Registry.: EG 674., Lab. Sanderson S.A., EXP.: 11/2016; Diazepam $10 \mathrm{mg} / 2 \mathrm{ml}$ solution for injection ampoules SOL. Sanitary Registry. I:S:P: F-6148/10, Lab. Sanderson S.A., EXP: 12/2017;Caffeine in tablets Sanitary Registry: N-24400, Lab. Naturales y Genéricos S.A.C EXP: 10/2016; and distilled water.

\section{Ethanolic extract's preparation}

The extract was prepared following the methodology described by Márquez-Vizcaíno Rita Luz et al. ${ }^{23}$ Dry ground barkmaterial of M. Macrocarpa (Ruiz \&Pav.) Briq.was macerated for one week in $70 \%$ ethanol. The mixture was filtered and reduced in arotavapor. This product was dried in a stove for 48 hours and it was milled in a mortar until a fine powder was obtained.This was stored in hermetic containers in the refrigerator for future use. The final product was dissolved in distilled water in the appropriateconcentration for a volume of oral administration not higher than $0.25 \mathrm{ml}^{21}$

\section{Irwin Test in mice}

The substance that was given to mice was triple-blind and they were observed for 1 hour in time ranges of 15, 30, 45 and 60 minutes. Before the evaluation, mice were placed in special cages with dimensions of $32 \times 14 \times 13 \mathrm{~cm}$. The variables analyzed were the presence or absenceof lethality, convulsions, Straub tail, sedation, excitation, abnormal gait (rolling or tip toe), jumping, motor in coordination, piloerection, abdominal writhes, stereotypies (smell, chew, head movements), head twitches, scratching and breathing abnormalities.

\section{Forced swim test in mice}

The forced swim test in mice is previously described by Roger D. Porsolt. ${ }^{13}$ For this test, Macrolon glass tanks separated by opaque sheets were used. The tanks were filled with water to a height of approximately $20 \mathrm{~cm}$, at a temperature of $23^{\circ} \mathrm{C}$. Mice entered to the experimental room one hour before the begining of the test, for their acclimatization. The following conditions were checked: room temperature of $21^{\circ} \pm 3^{\circ} \mathrm{C}$, humidity of $30-70 \%$, levels of noise less than $70 \mathrm{~dB}$. Mice were placed in the tanks, to measure their motion for 6 minutes. The first two minutes were for acclimatization, and the last four were accounted for measurement. The measurement parameter was the immobility time. ${ }^{13}$

\section{Design of experimental groups}

Eleven experimental groups were formed, made up of 7 mice each.These received the following substances: Group 1 (control), didn't receive substance; the following groups received the substances by oral administration: Group 2 or Placebo, received distilled water $0.1 \mathrm{ml} / 10 \mathrm{~g}$ of body weight; Group 3, Haloperidol 5 mg / kg PO; Group 4, Diazepam 32 mg / kg PO; Group 5, Fluoxetine 30 mg / kg PO; Group 6 Caffeine 32 mg / kg PO; Group 7 to 11, ethanol extract of the bark of $M$. macrocarpa (Ruiz \&Pav.) Briq. inescalating doses of 200, 400, 600, 800, and $1000 \mathrm{mg} / \mathrm{kg}$.

\section{Blind and control system}

A triple-blind system was applied in which the person that administrated the solutions, observed the reactions, and performed the statistical analysis, didn't know the origin of these solutions. ${ }^{24}$ Noise levels, humidity, room temperature and swimming tanks were monitored using VWR hygrometer model Thomas Traceable ${ }^{\circledast}$ Digital Humidity/Temperature Meter $35519-045$ with a capacity to measure humidity from $60 \%$ to $82 \%$ and a temperature range from $5^{\circ} \mathrm{C}$ to $34^{\circ} \mathrm{C}$, a sound level digital indicator Radio Shack 33-2055, able to measure from 60 to $120 \mathrm{Db}$, a insertion thermometer for water temperature of the forced swimming test, manufactured by Isolabwith measurement capabilities from $-50^{\circ} \mathrm{C}$ to $300^{\circ} \mathrm{C}$, two fan heaters to maintain a stable temperature of the room, brand NF15C 1500 WImaco with 2 heat intensities: 1000-2000W for an area of $15 \mathrm{~m}^{2}$. Research assistants were trained to explore physical manifestations using the Pharmacology Lab Virtual Software, ${ }^{25}$ and Microlabs ${ }^{26}$ and by an in vivo pilot.

\section{Ethics and research}

The study was approved by the Research Institute of the FMH-USMP following the International Guiding Principles for Biomedical Research Involving Animals ${ }^{21}$ and the Declaration of the Use of Animals in Biomedical Research ${ }^{27}$

\section{Statistical analysis}

The data, respectively, is presented as mean and standard deviation, and absolute and relative values. For quantitative variables the following statistics were applied: ANOVA 1 tail, Tukey and Newman-Keuls test, Kolmogórov-Smirnov test, and Pearson product-moment correlation coefficient. Statistical significance was established to a valuep $<0.05$, and a confidence interval of $95 \%$. For qualitative variables, Fisher's statistic was applied, considering statistical significance for a value $\mathrm{p}<0.05$, and a confidence interval of 95\%. Microsoft Office Excel 2013 and the statistical program Graph Pad Prism version 5.01 were used as computing support.

\section{RESULTS}

ANOVA test showed a p-value $<0.05$ in Forced Swim Test. Tukey's range test obtained a p-value $<0.05$ among groups 3 andgroup 5; group 5 andgroup 1, 2, 6 y 11; group 8 andgroup 6 . Nevertheless, when comparing group 3 against group 8 there was no statistically significant difference ( $\mathrm{p}>0.05)$ (Table 1).

Regarding the effect measured as immobility time in the administration of escalated doses of Maytenus macrocarpa, there was no linear 
Table 1: Immobility time in experimental groups

\begin{tabular}{|c|c|c|c|c|c|}
\hline Groups & Substance/Drug & $\mathrm{N}$ & Mean & $\begin{array}{l}\text { Standard } \\
\text { deviation }\end{array}$ & $\begin{array}{c}\text { Kolmogórov-Smirnov } \\
\text { Test } \\
\text { (Gaussian } \\
\text { distribution) }\end{array}$ \\
\hline $\mathrm{G1}^{*}$ & Control & 7 & 17.77 & 12.29 & YES \\
\hline $\mathrm{G}^{*}$ & $\begin{array}{c}\text { Placebo (Distilled } \\
\text { water) }\end{array}$ & 7 & 32.08 & 43.89 & NO \\
\hline $\mathrm{G}^{*}$ & Haloperidol & 7 & 91.77 & 76.03 & YES \\
\hline G5 & Fluoxetina & 7 & 22.77 & 21.93 & NO \\
\hline G7 & $\begin{array}{c}\text { M. macrocarpa } \\
200 \mathrm{mg} / \mathrm{kg}\end{array}$ & 7 & 45.38 & 57.30 & NO \\
\hline $\mathbf{G 8}^{*}$ & $\begin{array}{l}\text { M. macrocarpa } \\
400 \mathrm{mg} / \mathrm{kg}\end{array}$ & 7 & 73.69 & 70.65 & YES \\
\hline G9 & $\begin{array}{c}\text { M. macrocarpa } \\
600 \mathrm{mg} / \mathrm{kg}\end{array}$ & 7 & 36.31 & 37.94 & NO \\
\hline G10 & $\begin{array}{c}\text { M. macrocarpa } \\
800 \mathrm{mg} / \mathrm{kg}\end{array}$ & 7 & 40.92 & 45.46 & NO \\
\hline G11* & $\begin{array}{l}\text { M. macrocarpa } \\
1000 \mathrm{mg} / \mathrm{kg}\end{array}$ & 7 & 22.38 & 19.13 & NO \\
\hline
\end{tabular}

${ }^{*}$ Tukey's range test $\mathrm{p}<0.05$, for immobility time between groups: 3 and $5 ; 5$ and 1,2, 11 .

${ }^{\dagger}$ Groups 4 and 6 are not shown in this table because they weren't considered for the Forced

Swim Test.

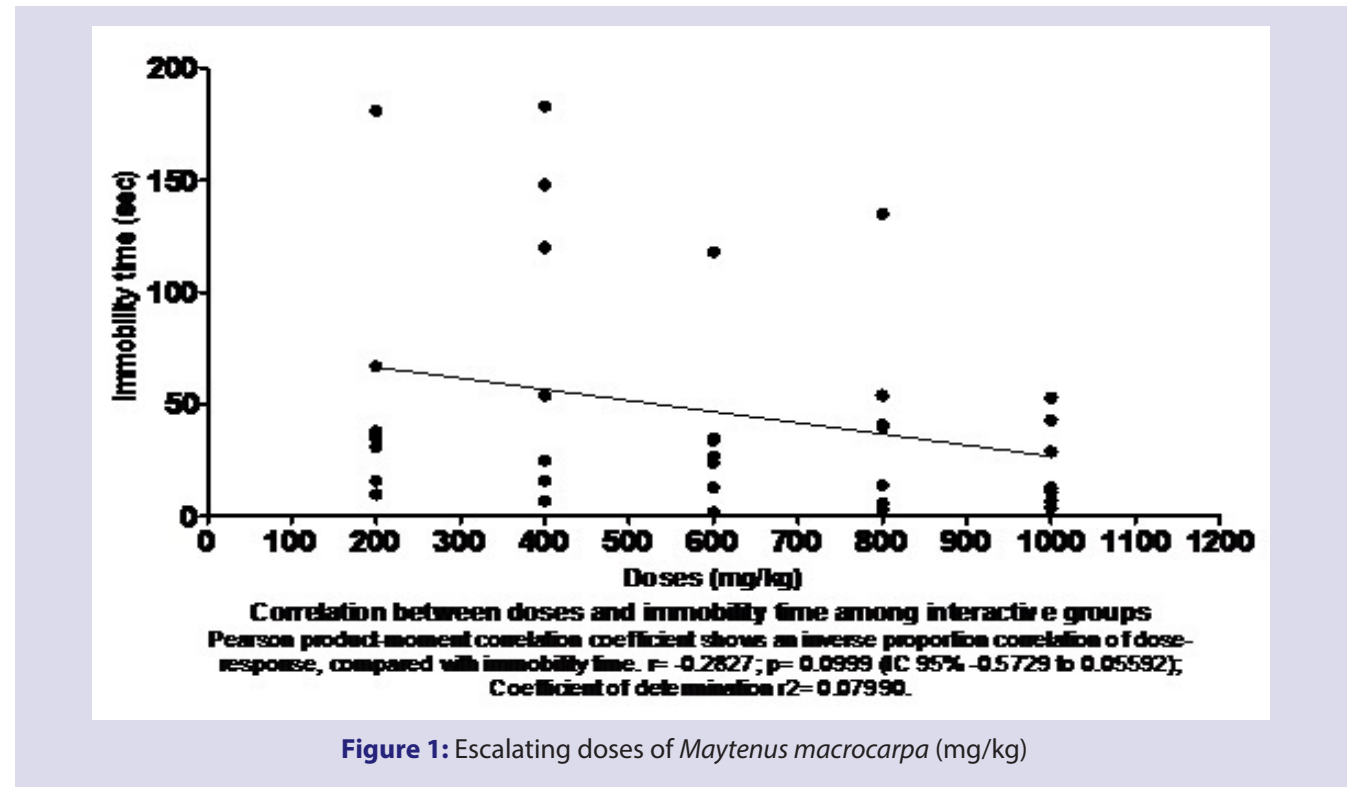

tendency in the dose-response relation, showing an inverse proportion correlation $(\mathrm{r}=-0.2827)(\mathrm{p}=0.0999$ IC $95 \%-0.5729$ a 0.05592$)$, with a determination coefficient $\mathrm{r} 2=0.07990$. On the other hand, the highest immobility time was registered in Maytenus macrocarpadose of $400 \mathrm{mg} / \mathrm{kg}$, which later compared with Haloperidol (positive control), according to Tukey's range test, obtained a p-value $>0.05$ (Figure 1).

Kolmogórov-Smirnov test, for Haloperidol and Maytenus macrocarpa of $400 \mathrm{mg} / \mathrm{kg}$, presented Gaussiana distribution.

The comparison made between Haloperidol and Maytenus macrocarpa in doses of 200,600 and $800 \mathrm{mg} / \mathrm{kg}$ revealed ap-value $>0.05$. KolmogórovSmirnov test determined non Gaussian distribution for Maytenus.
However, comparison made between Haloperidol and Maytenus macrocarpa of $1000 \mathrm{mg} / \mathrm{kg}$ displayed a p-value $<0.05$ at Tukey's range test. Kolmogórov-Smirnov test obtained a non-Gaussian distribution.

Comparing Fluoxetine with Maytenus macrocarpa groups, Tukey's range test got a p-value $>0.05$. When analizing with Kolmogórov-Smirnov test, Fluoxetine presented non Gaussian distribution (K-S distance $=0.2660, \mathrm{p}=0.0124$ ). In the Irwin Test, referring to control group, sedation in neurodepressant groups (Diazepam), group 9 and 11, was registered. The control group presented effects from minute 15, getting the highest effect at minute 30 . On the matter of the neurodepressant group, it presented its effect on the first 15 minutes, and kept constant until minute 60. For Maytenus macro- 


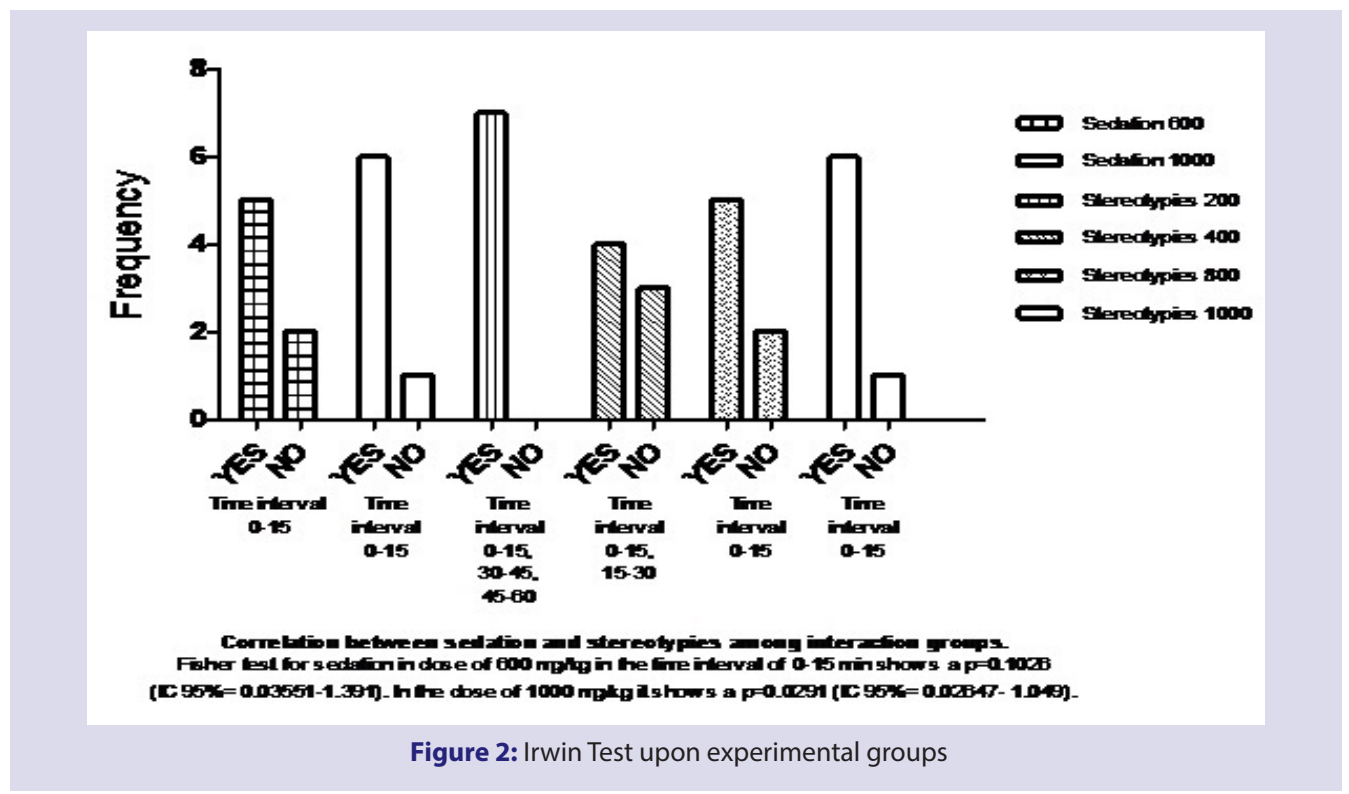

carpa groups, (7-11) every dose administrated presented sedation effect, nevertheless, not all mice from the groups were equally affected, because $56 \%$ of mice in those groups did not show sedation. Nevertheless, in 200 $\mathrm{mg} / \mathrm{kgdose}$, sedation effects were shown at minute $30 ; 400 \mathrm{mg} / \mathrm{kg}$ dose at minute 15 and 45; finally, doses of $600,800 \mathrm{mg} / \mathrm{kg}$ and $1000 \mathrm{mg} / \mathrm{kgin}$ the first 15 minutes (Figure 2).

In the case of excitement, control group and neurostimulant group were the only ones who presented it. Presence of jumps was observed in group 7. Additionally, every group presented piloerection, while stereotypies were only observed in groups: neurostimulant, 7, 8, 10 and 11 (Figure 2). Finally, neurodepressant group (Diazepam) displayed poor breathing compared with the beginning of the test. Only some of these results have been considered in order to create a summary graph, because others were not significant enough.

\section{DISCUSSION}

According to the forced swim test, Haloperidol was chosen as a positive control, which has an antipsychotic effect because it is a non-selective blocker of dopamine D2 receptors in the brain. ${ }^{28}$ When compared to doses of 200400,600 and $800 \mathrm{mg} / \mathrm{kg}$ of Maytenus macrocarpa, it didn't show a statistically significant difference, revealing a potential neuroleptic effect.

In contrast, a study of Maytenus obtusifolia MART root, demonstrated antipsychotic effect in the experimental model of catalepsy, ${ }^{10}$ therefore, this study expanded the evidence of the neuroleptic activity to the macrocarpa species, more precisely, the bark.

This antipsychotic effect could be explained with the secondary metabolites of the genus Maytenus. For example, the presence of triterpenic compounds and a theircentral nervous system depressant effect, with a yet unclear mechanism of action. ${ }^{29}$

One of the triterpens studied in different plants, which could also be found in our plant sample, was linalool, capable of inhibiting the binding of glutamate to the membranes of the cerebral cortex. ${ }^{30}$ Because of that, the release and uptake of glutamate is inhibited, suggesting a depressant effect on the central nervous system. ${ }^{31}$

In addition, the presence of other triterpens as maytenin and pristimerin has been demonstrated in the bark extract of Maytenus ilicifolia, which showed antioxidant activity. ${ }^{32}$ This effect is expressed by the release of dopamine metabolites, involved in neurons damage. ${ }^{33}$
Another secondary metabolites present in the genus Maytenus are the polyphenols. ${ }^{34}$ These could also explain the neuroleptic activity, because it has been shown that they have action upon the mitochondrial membrane potential, maintaining the transmission speed of nerve impulse, as well as the release of synaptic vesicles. ${ }^{35}$ A previous study about green tea polyphenols demonstrated to have antidepressant effect upon mouse behavior due to the hypothalamic-pituitary-adrenal axis. ${ }^{36}$ Another study evaluated the ability to swim of rats that were fed with polyphenols, obtaining a significant increase of swimming time, due to an increase of glycogen and ATP in rodents' muscles. ${ }^{37}$

In this study, for theforced swim test, a non-Gaussian distribution was observed at doses of 200, 600, 800 and $1000 \mathrm{mg} / \mathrm{kg}$ of Maytenus macrocarpa. This dispersion could be explained by some pharmacokinetic influence, considering that other investigations have demonstrated cytochrome P450 action upon flavonoids. ${ }^{38}$ An investigation about cytochrome P450 action upon flavonoid metabolism indicates that humans as well as mice, show cytochrome P450 complex in the liver microsomes and membranes, specially CYP1A2. This isozyme shows a great effect as a flavonoid metabolism inhibitor. ${ }^{38}$

An important effect that was registered in multiple doses, at the Irwin test for Maytenus macrocarpa, was sedation, which matches with a study about Maytenus obtusifolia bark's extract. This study used amphetamineinducedtoxicity test in order to verify the protective value of Maytenus obtusifolia, and described as a probable mechanism of drug action, the interference with the central neurotransmission of dopamine. ${ }^{10}$ Furthermore, a preclinical study demonstrated that flavonoids such as kaempferol, isolated from Maytenus ilicifolia leaves, ${ }^{8}$ and its glycosides, had an anxiolytic activity due to a bond with $\mathrm{GABA}_{\mathrm{A}}$ receptors. ${ }^{39}$

We found an interesting result in the jumping variablein the doses of 600 , 800 and $1000 \mathrm{mg} / \mathrm{kg}$ of Maytenus macrocarpa, where there was no statistically significant difference with the neurodepressant group (Diazepam). This could have happened because of a flavonoid (hyperoside), which was found in leaves of Maytenus ilicifolia and M. aquifolium (Celastraceae). This flavonoid has depressant central nervous system activity and at the same time, anti-depressant activity through dopaminergic pathways, according to the experimental model of forced swim test in rats. ${ }^{40}$

We also found piloerection in all the doses of Maytenus macrocarpa. That might have been provoked by the action of muscarinic receptors in the piloerector muscle. ${ }^{41}$ 
Finally, we found a non significant result in the variable stereotypies, which presented a neuro stimulation pattern as it happened with the application of caffeine. The results in our investigation showed a significant neuroleptic and sedative effect in the experiment with mice. This could be an advantage against typical antipsychotic drugs as these drugs produce hypnosis but not sedation. The pharmacological therapy could improve because sedation will control the psychomotor agitation in a patient with psychotic breakdown and the patient could be calmed without the need of inducing hypnosis.

The principal limitation of our study is that it cannot delimit the action mechanism or place. Also, we evaluated the effects of the whole extract and not the effects of each secondary metabolite that belonged to the bark, so differences could be found. For future studies, examination of the metabolites effects and level of action of each one should be made.

\section{CONCLUSION}

The antipsychotic effect and behavior modifying effect were demonstrated in Maytenus macrocarpa ethanolic extract.

\section{ACKNOWLEDGEMENT}

To Dr. Frank Lizaraso Caparó, Dean of Facultad de Medicina Humana, Universidad de San Martín de Porres, for his invaluable support and continued collaboration. To Dr. Benjamín Castañeda Castañeda, Past Director of the Research Institute of the FMH-USMP for his support and help during all the investigation.

\section{CONFLICT OF INTEREST}

The authors declare no conflicts of interest.

\section{REFERENCES}

1. Minagri. Dirección General Forestal y de Fauna Silvestre. [Online].; 2013. Available from: http://dgffs.minag.gob.pe/index.php/riqueza-y-biodiversidad-de-especies.

2. Polivoy S. Entrevista al antropólogo Luis Eduardo Luna: Plantas que enseñan. [Online]. Available from:http://mithos.freeservers.com/luna1.htm

3. Mejía K, Rengifo E. Plantas Medicinales de Uso Popular en la Amazonía peruana. Instituto de la Amazonía Peruana. $2^{\text {nd }}$ ed. Lima; 2000.

4. Huaccho J. Efectos sobre la temperatura, frecuencia respiratoria, frecuencia cardiaca y electrocardiograma de Maytenus macrocarpa (Ruiz and Pav.) Briq. (chuchuhuasi). Revista Cubana de Plantas Medicinales 2012; 17(3): 233-43.

5. Robles-Pizarro V, Tarqui-Cabrera L, Rodríguez-Collazos N. Efecto antinociceptivo del extracto etanólico de las hojas de Maytenus macrocarpa (Ruiz \& Pav.) Briq "chuchuhuasi" mediante la prueba de contorsiones abdominales en ratones. Revista Horizonte Médico 2014; 14(1): 6-10.

6. Acosta LG, et al. Efecto de Maytenus macrocarpa Chuchuhuasi en el sistema reproductor masculino del ratón (Mus musculus). Revista Peruana de Biología 2013; 20(3): 223-5.

7. González AG, Bazzocchi IL, Moujir L, Jiménez IA. Ethnobotanical uses of celastraceae. Bioactive metabolites. Bioactive natural Products (Part D). 2000; 23 649-738.

8. Leite J, Rastrelli L, Romussi G, Oliveira A, Vilegas J, Vilegas W, et al. Isolation and HPLC quantitative analysis of flavonoid glycosides from Brazilian beverages (Maytenus ilicifolia and M. aquifolium). J Agric Food Chem. 2001; 49(8): 3796-801.

9. Raymundo TM ea. Genotoxicity of the medicinal plant Maytenus robusta in mammalian cells in vivo. Genetics and molecular research 2012; 11 (3): 2847-54.

10. De Sousa, De Almeida. Neuroleptic-like properties of the chloroform extract of Maytenus obtusifolia Mart. Roots. Biological and Pharmaceutical Bulletin 2005; 28(2): 224-5

11. Leme Tods S, Prando T, Gasparotto F, de Souza P, Crestani S, de Souza L, et al. Role of prostaglandin/cAMP pathway in the diuretic and hypotensive effects of purified fraction of Maytenus ilicifolia Mart ex Reissek (Celastraceae). Journal of Ethnopharmacology 2013; 150(1): 154-61.

12. Dos Santos $V$, Leite K, Da Costa Siqueira M, et al. Antiprotozoal activity of quinonemethide triterpenes from Maytenus ilicifolia (Celastraceae). Molecules 2013; 18(1): 1053-62

13. Castagné V, Moser P, Roux S, Porsolt R. Rodent Models of Depression: Forced Swim and Tail Suspension Behavioral Despair Tests in Rats and Mice. In Current
Protocols of Pharmacology 2007; 55(8.10): 11-8.

14. Roux S, Sablé E, Porsolt R. Primary Observation (Irwin) Test in Rodents for Assesing Acute Toxicity of a Test agent and its effects on Behavior and Physiological Function. In Current Protocols in Pharmacology 2004; 10(10): 1-23.

15. Cerrate E. Manera de preparar plantas para un herbario. Lima: Museo de Historia Natural. Universidad Nacional Mayor; 1969.

16. Brako L, Zarucchi J. Catalogue of the flowering plants and gymnosperms of Peru. Monogr Syst Bot Mo Bot Gard. 1993; 45: 1-1286.

17. Macbride J. Celastraceae, Flora of Peru. Publ Field Mus Nat Hist Bot Ser. 1951; 13(02): 259-70.

18. Vásquez Martínez R. Flórula de las reservas biológicas de lquitos, Perú: Allpahuayo-Mishana, Explornapo Camp, Explorama Lodge. Monogr Syst Bot Mo Bot Gard. 1997; 63: 1-1046.

19. Funk $V$, Hollowell $T$, Berry $P$ et al. Checklist of the plants of the Guiana Shield (VENEZUELA: Amazonas, Bolivar, Delta Amacuro; Guyana, Surinam, French Guiana). Contributions from the United States National Herbarium 2007; 55 $1-584$

20. Killen T, Schulenberg T. A biological assesment of Parque Nacional Noel Kempff Mercado, Bolivia. Rapid Assess Program Work Pap 1998; 10: 1-372.

21. Council for Organizations of Medical Sciences. International Guiding Principles for Biomedical Research Involving Animal. In; 1986. p. 553-4.

22. Lazcano Ponce E, Salazar Martínez E, Gutiérrez Castrellón P, Angeles Llerenas A, Hernández Garduño A, Viramontes JL. Ensayos clínicos aleatorizados: variantes, métodos de aleatorización, análisis, consideraciones éticas y regulación. Salud pública Méx. 2004; 46(6): 559-84.

23. Márquez Vizcaíno R, de la Rosa C, Mercado Perez A. Actividad antifúngica del extracto total en etanol de las hojas frescas de Pedilanthus tithymaloides $\mathrm{L}$. Scientia Et Technica. 2007; 13(33): 155-9.

24. Galduf J, Gallego C, Escrivá J, Monserrat V. Ensayos Clinicos: Elaboracion De Una Lista-Guia Para La Valoracion De Protocolos. Farm Hosp. 1995; 19(1): 17-23.

25. Mujica J PY. Procesamiento de señales in vivo, edición audivisual y creación de un prototipo de software educativo para simulación de experimentos en farmacología. Tesis para optar el grado de Bachiller en Ingenería Electrónica. Lima: Universidad San Martín de Porres; 2009.

26. Wilgenburg HV. Microlab for Pharmacologist. [Online]. Available from:http://oslovet.norecopa.no/produkt.aspx?produkt=5381

27. Asociación Médica Mundial. Declaración de la Asociación Médica Mundial sobre el uso de animales en la investigación biomédica. Hong Kong; 1989.

28. Goodman L, Gilman A, Brunton L, et al. Goodman and Gilman Las bases farmacológicas de la Terapéutica. 12 ${ }^{\text {th }}$ ed. México: McGraw-Hill Education; 2012.

29. Chávez H. Friedelane triterpenoids from Maytenus macrocarpa. Journal of Natural Products 1998; 61(1): 82-5.

30. Elisabetsky E, Silva Brum L, Souza D. Anticonvulsant properties of linalool on glutamate related seizure. Phytomed. 1995; 6(2): 113-9.

31. Silva Brum L, EmanuelliT, Souza D, et al. Effects of linalool glutamate release and uptake in mouse cortical synaptossomes. Neurochemical Research 2001; 26(3): 191-4.

32. Dos Santos V, et al. Evaluation of Antioxidant Capacity and Synergistic Associations of Quinonemethide Triterpenes and Phenolic Substances from Maytenus ilicifolia (Celastraceae). Molecules 2010 October; 15(10): 6956-73.

33. Santiago López D, Rivas Arancibia S. Estrés oxidativo, metabolitos oxidados de dopamina y enfermedad de Parkinson. Revista Faculta de Medicina UNAM 2008; 15(3):104-7.

34. Rengifo Salgado E. Contribución de la Etnomedicina-Plantas medicinales a la salud de la población en la Amazonía. Instituto de Investigaciones para la Amazonía peruana - IIAP; 2010.

35. Fuentealba Arcos J, Guzmán L, Aguayo L. Compuestos Neuroactivos Obtenidos Desde Fuentes Naturales: Caracterización Farmacológica De Neuromoduladores Del Snc. Rev. Farmacol. Chile 2012; 5(2): 55-62.

36. Siddalinga Swamy M, Sivanna N, Tamatam, Khanum F. Effect of Poly Phenols in Enhancing the Swimming Capacity of Rats. Functional Foods in Health and disease 2011; 1(11): 482-91.

37. Zhu W, Shi H, Wei Y, Wang S, Sun C, Ding Z, et al. Green tea polyphenols produce antidepressant-like effects in adult mice. Pharmacological Research 2012; 65(1): 74-80.

38. Breinholt VM, et al. In vitro investigation of cytochrome P450-mediated metabolism of dietary flavonoids. Food and Chemical Toxicology 2002 May; 40(5): 609-16.

39. Burgos-Moron E, Perez-Guerrero C, Lopez-Lazaro M, Calderon-Montano J. A Review on the Dietary Flavonoid Kaempferol. Mini Reviews in Medicinal Chemistry 2011 April; 11(4): 298-344.

40. Haas J, Stolz E, Betti A, Stein A, et al. The Anti-Immobility Effect of Hyperoside on the Forced Swimming Test in Rats is Mediated by the D2-Like Receptors Activation. Planta Med. 2011 March; 77(4): 334-9.

41. Kurzen $H$, Berger $H$, Jäger $C$, Hartschuh W, Näger $H$, Gratchev A, et al. Phenotypical and Molecular Profiling of the Extraneuronal Cholinergic System of the Skin. Journal of Investigative Dermatology 2004 October; 123(5): 937-49. NO 


\section{ABOUT AUTHORS}
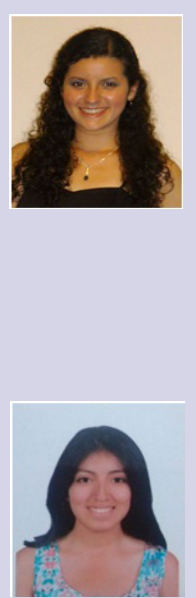

Claudia Zambrano Santoyo: Is a Junior Researcher and student currently at $4^{\text {th }}$ year of Medical School at Universidad de San Martin de Porres. Her clinical practices are at Hospital Nacional Arzobispo Loayza. Her research interests include the pharmacological effects of the Peruvian medicinal plants, especially central nervous system, in order to improve existing information about the plants of common use in communities. She is also interested in Internal Medicine, and hopes to keep developing researches in the following years of her medical education.

Lucero Zúñiga Espinoza: is a Junior Researcher and medical student from Facultad de Medicina Humana at Universidad de San Martin de Porres. She is member of the SOCIEDAD CIENTIFICA DE ESTUDIANTES DE MEDICINA HUMANA (SOCIEM-USMP), which's main goal is to promote research. Besides, she was local officer of the Standing Committee of Public Health from the International Federation of Medical Student's Association (IFMSA), where she organized and participated in projects related to prevent diseases and create future public health qualified leaders. She has one published paper related to malnutrition in Peruvian children. Currently, she is doing her medical practice at Hospital Nacional Guillermo Almenaralrigoyen. Her research interest includes demonstrating the medical properties of Peruvian plants for a later use as drugs, especially for cardiologic pathologies and central nervous system effects. She is considering becoming a cardiologist.

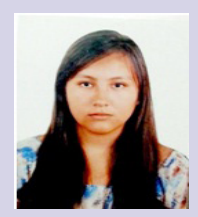

Rosario Zanabria Puente: Is a Junior Researcher and student of Medical School, at her $4^{\text {th }}$ year, at Universidad de San Martin de Porres. At this moment, she is doing her clinical practice at Hospital Nacional Daniel Alcides Carrión. She plans to develop more researches about medicinal plants with origins on her country, especially to demonstrate central nervous system effects. In a future she would like to specialize in Clinical Pathology.

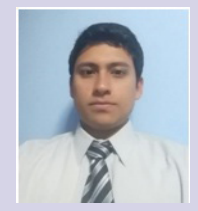

Joshi Zegarra Sánchez: Is a Junior Researcher and student currently at $4^{\text {th }}$ year of Medical School at Universidad de San Martin de Porres. His clinical practices are at Hospital Nacional Hipólito Unanue, hospital that has specialized spaces for patients with tuberculosis. His research interests include the pharmacological effects of the Peruvian medicinal plants, especially central nervous system effects and properties affectingcardiovascular system, being Cardiology the specialty he plans to achieve.

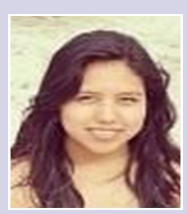

Nathaly Zaga Quispe: Is a Junior Researcher and student of Medical School, currently at her $4^{\text {th }}$ year at Universidad de San Martin de Porres. Her clinical practices are at Hospital Nacional HipólitoUnanue. Among her research interests, there are the pharmacological effects of the Peruvian medicinal plants, especially central nervous system effects. Also, she hopes to specialize in either Endochrinology or Pneumology.

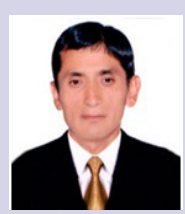

Carlos Pante Medina: Is a laboratory technician at the Centro de Investigación de Medicina Tradicional y Farmacología of the Facultad de Medicina Humana de la Universidad de San Martin de Porres, Lima, Peru. He is specialized in animal experimentation.

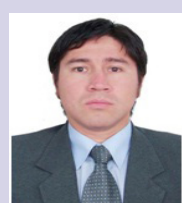

Alberto Salazar Granara: Is a Professor in Pharmacology and Researcher at the Centro de Investigación de Medicina Tradicional y Farmacología of the Facultad de Medicina Humana de la Universidad de San Martin de Porres, Lima, Peru. His research interests are the pharmacological effects of the Peruvian medicinal plants, especially central nervous system effects, anti-inflammatory and analgesic properties. He is also interested in discover off-label effect from the common antihypertensive, antidiabetic, antidepressants and analgesic drugs. He is also interested in exploring the pharmacogenetic and pharmacokinetic highlight markers in Peruvian population, applied in important pathologies like Peruvian tuberculosis, hypertension, diabetes and others. 